\title{
From the Tobacco Shop to the Cigarette Factory: Technological Changes, Gender and Surveillance in a Greek Cigarette Firm in the Early 20th Century
}

\author{
Thanasis Betas \\ University of Thessaly, Volos, Greece \\ Email: abetas2@hotmail.com
}

Received 6 January 2016; accepted 11 April 2016; published 14 April 2016

Copyright (C) 2016 by author and Scientific Research Publishing Inc. This work is licensed under the Creative Commons Attribution International License (CC BY). http://creativecommons.org/licenses/by/4.0/

\section{(c) (;) Open Access}

\begin{abstract}
How did the technology and the mechanization of production affect the organization and division of labor in Matsagos cigarette industry in the city of Volos? Who worked in the machinery and in the new labor departments and what was their role? Did the technological equipment play a role in the formation of professional specialties which existed in the factory? How are the technical and gender labor division interweaved? These specific changes of the field of cigarette-makers are going to be traced through our case.
\end{abstract}

\section{Keywords}

Cigarette Industry, Technological Changes, Gender, Labor

\section{Introduction}

The systematic manufacture of handmade cigarettes began in the public tobacco-factories of Greece in about 1890. The first cigarette-makers arrived in Greece from Istanbul and Alexandria, where the manufacture of handmade cigarettes had already begun. A few years later-mainly in the 1910s and 1920s — the introduction of cigarette-making machines, the mechanization of the field and, finally, the prohibition of handmade cigarettes rendered the profession of cigarette-maker inoperative, at least regarding handmade cigarette-making. In what follows, I will trace these changes in the field of cigarette manufacture.

More specifically, the present study focuses on cigarette makers and cigarette production. It looks into the changes in the labor process and the social relations of production after the sweeping mechanization in the early 
20th century. In examining the process of cigarette production after the mechanization of the field in Greece, I turn to a cigarette industry that operated in the city of Volos from 1918-1972 and I investigate the consequences of technological and organizational modifications on labor. How did the technology and the mechanization of production affect the organization and division of labor at the Matsagos cigarette industry in Volos? Who worked in the machinery and in the new labor departments and what were their duties? Did the technological equipment play a role in the emergence of the factory's professional specialties? And, finally, how was the division of labor at the technical and gender levels interweaved?

In Volos and at the Matsagos cigarette factory, and generally in the biggest cigarette factories of interwar Greece, the presence of a reserve labor force after the Greek-Turkish war of 1919-1922 that included women refugees from Asia Minor, led to even greater expansion of the factory system. This in turn led to the introduction of new machinery that eventually rendered the manual skills of the cigarette makers completely redundant. However, the productivity at Matsagos did not mainly or exclusively rely on the machinery but mostly on the intensity of female labor: alongside the mechanization of production there were traditional posts that required manual work executed by women. Is the technological development connected to the presence of the women refugees in the Matsagos factory? What effect did this specific workforce have on the choice of technical change and on the organization of labor in that particular context?

To examine these issues, I have selected directly relevant material from the Matsagos cigarette factory archive: staff records, employee cards, labor union records, board of director records, technical compositions and payrolls, as well as photos and oral testimonies. These documents allow us to examine issues that concern the labor process and, generally, the labor organization there, as well as the specializations and the workforce composition on a sector-by-sector basis. Finally, the framework of this study concerns Volos from the closing decades of the 19th century to the first decades of the 20th century. The city and the factory seem to follow "parallel roads". Nick Matsagos established a small tobacco shop in post-Ottoman Volos, just nine years after the city and Thessaly became part of Greece in 1881. As the city expanded at the turn of the century, the tobacco shop transformed itself into a cigarette factory.

This article is divided into three parts. In the first part, I provide an overview of the consequences of mechanization in the cigarette industry internationally in the early twentieth century. Towards the end, I turn my attention to the Greek cigarette industry, tracing its development from its beginnings to the 1930s in order to put together a general picture of the Greek context in which our case is based. The main body of this article-i.e., the second and third parts-focuses on the Matsagos cigarette factory. It examines its relationship with the young women refugees from Asia Minor as well as the effects of the technological changes on the division of labor at the factory during the first decades of the 20th century.

\section{The Effects of Mechanization in the Cigarette Industry at the Dawn of the 20th Century. A Comparative Approach}

During the first decades of the 20th century, almost the entire world adopted a certain type of tobacco product: the cigarette. The invention of the cigarette-making machine by James A. Bonsack is one of the most important events in the history of tobacco production. Internationally, the mechanization of production signalled the transition from the hand-made cigarette to the industrial cigarette (Porter, 1969: pp. 59-76). The mechanization of the cigarette industry meant the modification and the harmonization of the organization of production by gender all over the world. When Bonsack's cigarette-making machine appeared in the market in the 1880s, a gender division of labor took place in all the countries with a cigarette industry. This imposed the execution of different tasks by men and women in the workplace. Technology and professional segregation based on gender were tightly interwoven concepts in the tobacco industry and more specifically in cigarette production, but not everywhere.

In countries without a major tradition in cigarette-making such as the USA, the increase in cigarette consumption in the first years of the 20th century led to an increase in the percentage of women's employment. According to Lina Galvez-Munoz, the domination of female labour or the "feminization of tobacco industry", as she calls it, in the first quarter of the 20th century in the tobacco industry is due mostly to the triumph of the cigarette over other smoking habits, whose production was considered a female job (Galvez-Munoz, 2006: p. 10). In parallel, the domination of female labour is also the result of the mechanization of the branch. The mechanization of cigarette production in the US from 1880 onwards resulted in the production of a cheap and quite popular 
product, produced by machines that were handled by women (Hannah, 2006: pp. 66-67; Jones, 1984: pp. 441451).

In Europe, and more specifically in Spain, the mechanization of cigarette-making and the transition to industrial cigarettes threatened and eventually made redundant the skilled labour of women "cigarreras". The use of cigarette-machines since the late 19th century radically changed both the process of cigarette production and the labour relations in the field of cigarette-making, especially on issues related to the hiring and training of women in cigarette-making. Eventually, the broad mechanization of production in Spanish tobacco factories resulted in the end of the cigarreras and to an increase in unemployment among women. In the beginning of the 1920s in particular, when even the old cigarreras that had kept their jobs because of mechanization retired, tobacco industries began hiring young unskilled girls (Radcliff, 1993: pp. 85-108).

Lina Galvez-Munoz claims that these new workers were the daughters of the old cigarerras, who were hired only if their mothers accepted to work at the machines in the factories. This, according to Galvez-Munoz, is in itself a plausible explanation why the cigarreras accepted the machines. With the final mechanization of cigarette production in Spain, the gender-based division of labour became the industry's main characteristic. Women operated the cigarette and cigar making machines, but were also employed in box-making and packing. Male workers were employed in the supervision of the factory grounds, in the maintenance of the equipment and the facilities, as well as in the operation and repair of the factory's machinery. A new labour aristocracy appeared with the mechanization of production in the cigarette industry: the mechanics, who were always men (Galvez Munoz, 1997: pp. 87-128). In contrast to this, in the Ottoman Empire machine operation was clearly a man's job. Using early 20th century photographic material of workers at their place of work at the Cibali factory, Istanbul, Gulhan Balshoy seeks to reconstruct the labour process and the division of labour. The Cibali factory was mechanized almost completely at the beginning of the 20th century, but the access to technology was strictly a male privilege. In contrast to this, women workers were always depicted in photographs engaged in manual jobs. Balshoy argues that the use of technology created new gender principles and hierarchies that are apparent in the photographs (Balsoy, 2009: pp. 45-68).

Up to a point, the situation that Balshoy describes may bring to mind the Greek cigarette industry, and more specifically the Matsagos factory. However, at the Matsagos factory female workers were not barred from the machines, but their presence was quite restricted in the mechanized departments of the factory. Female cigarette workers in these departments performed different tasks to those of their male colleagues. It remains true to say, however, that the introduction of machinery to the Greek cigarette industry created new facts. The advent of cigarette-making machines in the first two decades of the 20th century, the mechanization of the branch and, finally, the abolition of hand-made cigarettes rendered the job of cigarette-making inoperative. With a law that was passed on 22/5/1926, hand-made cigarettes as a distinct category were abolished in Greece and their marketing forbidden. Changing consumer tastes and smoking trends in Greece at the turn of the 20th century created a need for a massive production of tobacco products. This led a number of former tobacco sellers to establish cigarette factories in several cities around Greece. As will become clear from the case of the Matsagos cigarette industry, the appearance of machines in production, mostly in 1920s, led to a division of labour that involved a discrimination between male and female jobs. This imposed anew a separation of workers into "skilled" and "unskilled".

In conclusion, it may be said that if technology and gender are indeed interwoven in the cigarette industry all over the world, this happens in different ways and creates different relationships in the workplace, depending on the region and the country, as we noticed by comparing the above cases. Therefore, I argue that in order to understand these differences, cultural factors related to gendered perceptions, traditions, race, as well as religion should be taken into account. In other words, the question of the factors to which the differences that are noticed internationally in the field of cigarette industry may be attributed, is an intriguing question. It is, moreover, a question that allows us to connect industrial labour with places beyond the factory, particularly with the organization of social and gendered relations beyond the workplace. But this a question that goes beyond the scope of the present article.

\section{The Cigarette Industry in Greece in the First Half of the 20th Century}

The tobacco process allowed the Greek tobacco industry to become a major factor in the Greek economy. Tobacco exports constituted the basic export product of Greece from the early 20th century. Cigarette manufacture, on the other hand, developed in the narrow context of a light industry for internal consumption. Furthermore, 
beyond the existence of small family businesses, there was no considerable artisanship sector of hand-made cigarettes in Greece. As a result, cigarette-makers never developed a strong professional delivery-as was the case in countries such as Spain, the US and France-which would give them a strong negotiating position within the new labor relations about to be formed. The first cigarette-makers came to Greece from Istanbul and Alexandria, where the production of hand-made cigarettes had started earlier. After the establishment of the State Monopoly of Tobacco in the Ottoman Empire in 1876 many Greeks tobacco merchants and craftsmen left and settled in Egypt, where became involved in the tobacco trade and cigarette-making, establishing the first workshops and cigarette production factories (Schechter, 2006; Beinin, 2001).

Cigarette-production factories appeared from the mid 1910s in or next to commercial centres in southern Greece, in several cities. The first factories appeared together with the emergence of a market for their products, that is they had a "market orientation" (Labrianidis, 1982: p. 126). The basic factor that affected the location of the cigarette-making units was the existence of consumer centres to which products were channelled. The annexation of new districts and cities such as Salonica in northern Greece after the Balkan Wars in 1913, did not change the spatial distribution of cigarette factories. They remained concentrated in the cities of southern Greece though their products reached the country's northern parts, changing the smoking habits of their inhabitants.

The geographical region of Athens-Piraeus, the dominant consumer and trade centre in the early 20th century, attracted a considerable number of tobacco industries. This situation did not change during the interwar period. Cigarette-production factories during the first period of the interwar years existed in several cities, but mostly in southern Greece. However, there were tobacco industries in certain cities in the North too, such as Thessaloniki and Xanthi. But, in subsequent years one notices a trend of fewer and fewer tobacco factories in cities along with a diminution of production within factories.

With the Matsagos factory as its only tobacco unit, Volos reinforced its importance as a tobacco-industrial centre, increasing its share in the production from $15 \%$, in 1925, to $25 \%$, in 1939, of the total production. For its own part, Athens, which from 1925-1929 produced 40\% of the country's smoking products, dramatically decreased its share between 1935-1939 to 18.2\%. Similarly, Thessaloniki and Pyrgos substantially decreased their share of total production (from $7 \%$ to $1.5 \%$ and from $6.5 \%$ to $2.5 \%$ respectively for the respective periods mentioned below). Lastly, Kalamata remained stable in its production, maintaining $4 \%$ of the country's total production for the entire interwar period (Dritsa, 2004: pp. 64-69). Therefore, in the late 1930s, one can talk of the field's oligopolistic character since by far the biggest part of domestic production was concentrated in three factories: the "Papastratos" factory in Piraeus with $29 \%$ of the total production of the country, the "Matsagos" factory in Volos with $25 \%$ and the "Keranis" factory, also in Piraeus, with $11 \%$. It is possible that mechanization rendered the tobacco industries that could not follow technological developments non-competitive.

In summary one can say that during the last phase of the interwar period, we see an obvious trend towards the concentration of tobacco industries in certain urban centres. These centres, along with the regions of Athens and Piraeus, saw the biggest consumption as well as workforce availability. It is within this framework that one can see the development of the Matsagos cigarette industry in Volos.

\section{The Matsagos Cigarette Industry and the Women Refugees from Asia Minor}

With the inclusion of Thessaly to the Greek State in 1881, Volos entered a period of transformation. Within a few decades the structure of the city and the population itself underwent substantial changes. The two separate nuclei of the city - the Muslim and the Christian-became unified after the departure of the Muslim residents of the "Kastro" area following the 1897 war, and ethno-religious discrimination in the residential areas ceased (Hastaoglou, 2007: pp. 46-47). Few Muslims lived in Kastro at the turn of the 20th century. In 1901, there were just 10 families with a total of 70 Muslims. Muffi Halil effendi served the religious needs of the mosque as well as the teaching needs of the small school. Only a couple of families of Ottoman wholesale merchants lived in the new city (Volos Guide, 1901: p. 86). Volos very soon became the locus of vigorous industrial activity and became the second, after Piraeus, industrial centre of "Old Greece" at the end of the 19th century. Its population was on a steady rise - from 4, 987 residents in 1881 it reached 11,029 in 1889 and 23,563 in 1907-the activity around smoke was particularly intense, which concerned both the tobacco industrial processing and cigarettemaking (Censuses, 1881, 1889 and 1907), Figure 1. In "Guide-book of Volos” of 1901 one sees that 14 tobacco trade firms and 24 tobacco-shops are registered, among them Nick Matsagos. These were located on Dimitriados street, at the city centre, where almost all the tobacco shops of the era had set up their businesses (Volos Guide, 1901: p. 111), Figure 2. 


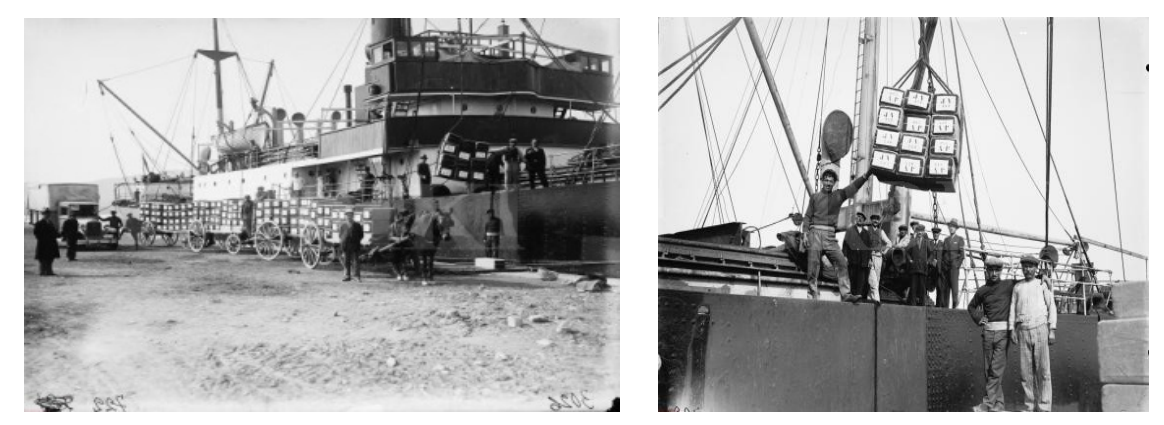

Figure 1. Transformations of tobacco in Volos port in the early 20th ct. (Zimeris’ Archive).
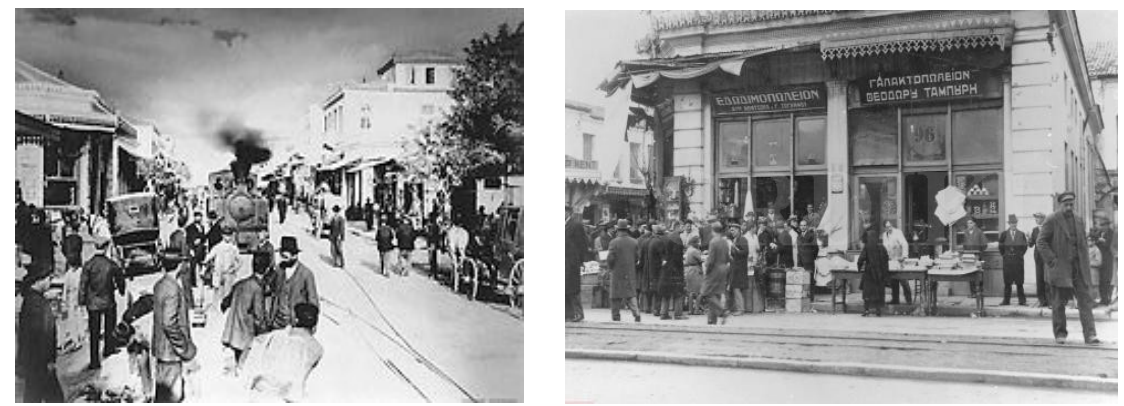

Figure 2. Volos, Dimitriados street in the early 20th ct. (Zimeris’ Archive).

Equivalently, the 1911 commercial guide "Volos-Pilio-Almyros" cites 18 tobacco-trade firms and 12 tobacco-shops, among them Nick Matsagos's (Christopoulos, 1911: pp. 46-47). As the city grew and smoking as a habit became increasingly popular, some tobacconists decided to jump from the tobacco trade and hand-made cigarettes to the cigarette industry. One of these tobacco sellers was Matsagos, from Pilio, who moved on from the tobacco trade and the small tobacco-shop he had opened in 1890 to the cigarette production industry, establishing the first private tobacco-cutting firm in "Old Greece" in 1919. The transition from small cigarette-making workshops to the Matsagos cigarette factory is signalled by the gradual expansion of the production unit as well as the rapid expansion of mechanical equipment, mostly during the 1920s.

In 1900, Nick Matsagos had founded a small tobacco factory in Volos. A few years later, in 1910, he imported the first tobacco-cutting machine, one of the first of a limited number to have been made by "Leng", a small firm in England. In 1918, after the end of World War I, his two sons, Ioannis and Constantinos, took over. A Limited Company was founded, whose general partners were Ioannis and Constantinos Matsagos, with their father as silent partner. In 1918 the cigarette production of the company was 3000 kilograms. It was Ioannis and Constantinos Matsagos who first took the decision to pull out of the tobacco trade and to deal exclusively with cigarette production. The factory employed almost 1000 workers during the interwar period. However, the death of the Matsagos brothers, in 1940 and 1942, and increased competition in the cigarette industry from the capital in the post-war period may have signalled the "beginning of the end" for the Matsagos cigarette industry. After a long period of intense problems that began in the mid-1950s, the Matsagos factory was initially put under compulsory administration in 1956, and was then bought by the Greek Bank of Industrial Development until its closure in 1972.

Diagram 1 shows a steady increase of the workforce of Matsagos tobacco factory during the interwar period, which continued during the 1940s. Where does this continuously expanding workforce come from and what role did it play in the development of the business? In order to answer this question, we will briefly examine a sample of 300 people who worked at Matsagos during the interwar period. Our sample comes from the archives of the firm and specifically from the "Personnel Register Cards". The "Personnel Register Cards" and the personnel lists concern each man and woman worker individually and include information about themselves from the first day of their employment in the factory until the day of their departure. More specifically, they include: Name and Surname, Parents' name, date of birth, place of origin, marital status and permanent address. They also mention the department and the post, the date of hiring and departure, as well as the reason for leaving the factory. Table 1 shows the place of origin of the 300 employees at Matsagos cigarette factory as it appears on 
number of employees per year in Matsagos

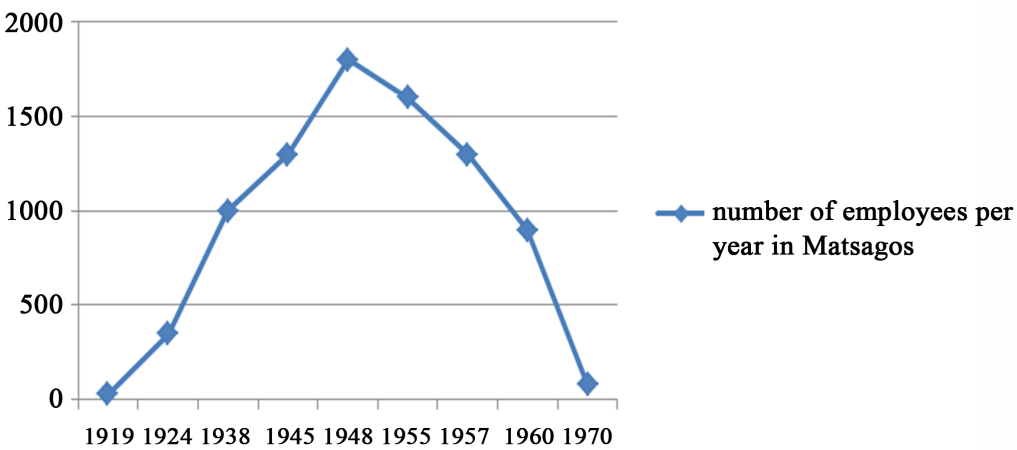

Diagram 1. Number of employees per year in Matsagos. Source: general archives of state, prefecture of magnesia, Matsagos archive, archive of labour centre of Volos.

Table 1. Places of origin of employees in the Matsagos cigarette industry during the interwar period.

\begin{tabular}{cccc}
\hline Origin & Male & Female & Total \\
Volos & 21 & 90 & 111 \\
Pelion Mountain & 12 & 35 & 47 \\
Asia Minor & 3 & 60 & 63 \\
Istanbul & 2 & 6 & 8 \\
Thessaly (Cities-Villages) & 12 & 28 & 40 \\
Other Cities and Villages of Greece & 5 & 10 & 6 \\
Non-Greek Locations & 1 & 5 & 300 \\
Total & 66 & 234 &
\end{tabular}

Sample 300 male and female workers. Source: Matsagos archive, personnel register cards.

the "Card". Note that the biggest part of the male and female workers, that is 111 workers of the sample's 300, stated as their place of origin the city of Volos. Of these, 90 are women and 21 men.

It seems that the villages of Pelion supplied the cigarette industry of Volos with a workforce: 35 male workers and 12 female workers come from several nearby or more remote villages of Pelion. Forty people who worked at Matsagos also came from the wider area of Thessaly (28 women and 12 men). Fifteen of these come from three neighbouring cities (Larisa, Trikala and Karditsa) and the other 25 from several towns and villages of the four prefectures of the broader Thessalian region. The specific record, which undoubtedly depicts a trend, confirms the fact that in the interwar period, Volos, as an important industrial centre, attracted domestic immigrants from the neighbouring countryside, from both Thessaly and Pelion. We can see that to a large extent, besides the city of Volos itself, the villages of Pelion and the region of Thessaly are the places of origin of the biggest part of the sample of male and female workers at Matsagos, i.e., a total of 198 workers out of 300.

Other than the domestic immigrants, that is people who came mostly from the Thessalian hinterland and Pelion and worked in Matsagos, a very important part of the workforce of the firm during the interwar period were women, mainly refugees from Asia Minor. This trend is apparent in the sample, too: 66 people from our sample, including the women from Istanbul. It seems that the reason that thousands of refugees settled permanently in Volos was the hope for occupational rehabilitation. Most refugees were occupied mainly in the secondary sector of the city and more specifically in the textile factories and the two tobacco sectors: processing and cigarette-making. If we take into account the statistics of the 1928 census, 57\% of the tobacco workforce in Volos was refugees, of which 77\% were women (National Statistics Department, 1928). At the same time, as became obvious earlier and is further supported by the details in the technical reports of the archive, the broad mechanization in Matsagos takes place in the 1920s. At least up to a point, this technological development is associated with the presence of women refugees at the Matsagos factory. 
More specifically, in Volos and in the Matsagos cigarette factory but also in the biggest cigarette industries of interwar Greece, reserve labour after the Greek-Turkish war of 1919-1922, made up, for instance, by women refugees from Asia Minor, led to further expansion of the factory system and to the introduction of new machinery that would render the presence of male skilled labour of cigarette makers completely redundant. However, the output at Matsagos was not mainly or exclusively based on the machinery but mostly on the intensity of female labour. Together with the mechanization of production, the existence of more traditional posts required manual work that was carried out by women.

At the same time, the increase of productivity and the ensuing expansion of the Matsagos factory, which became prominent during the 1920s, was based on a complex framework of labour organization, —as it is proved through the detailed business's archive that cannot be analyzed in depth in the context of this article- that concerned different systems of payments, temporal occupation, strict supervision and penalties for those who broke the rules, and, generally, systems which were constructed on relations of exploitation, discipline and control of the workforce. Finally, here, as well as elsewhere, the cheaper price of female labour seems to have been the main reason for its predominance over male labour. The concentration of a female workforce-mostly but not exclusively refugees-in the two branches of tobacco and in textiles is not seen only in Volos but in many areas of the country. Many, mostly young, women were part of the workforce in the tobacco and textile industry, leading to a further increase in the participation of women in the secondary sector during the interwar period (Avdela, 2002: p. 343). The personal female workers cards in the firm's archive are revealing.

Alexandra M. was born in Asia Minor in 1918. In 1929, at the age of 11, she got a job at Matsagos and remained there until the end of June 1942, completing eleven years of continuous work. She was hired again on 23 December 1943 and left permanently from the cigarette factory on April 1950 due to illness. Anna M. was born in Asia Minor too, in 1912. She worked for the first time at Matsagos when she was 12, as we can see from the employee's cards of the factory and she remained there for 21 consecutive years. On September 24, 1924, Areti P. entered for the first time the factory as well. She worked there until 1957, when she was fired. A year later, Erini K. from Asia Minor, was hired at the age of 13. Likewise, Artemis N. was thirteen years old and from Asia Minor. She got a job at Matsagos on May 27, 1925. Erini was employed there-with intervals—until 1960, which is for thirty five years.

The cases we mentioned above - there are too many like these in the archive of the enterprise-witness that female child labour in Matsagos-and more specifically labour of too young refugee girls from M. Asia—was an undeniable fact, even if this particular workforce was hid in boxes or in the factory's toilet each time the Labour Inspection visited the factory in order to check on it. Apart from the archive, the oral testimonies also seem to support our hypothesis. For example, Maria A. was employed in Matsagos for 23 years, from 1936 until 1959. She was from Asia Minor and the third child of a family of five children. She got a job in Matsagos, where her older sisters worked, when she was 13 years old. She narrates: "When the Labour Inspector came to the factory, we were hidden... into the large cigarette boxes or in the toilets... wherever... there were too many little girls those years in Matsagos".

The practice of child labour concealment from Labour Inspectors is engraved in Georgia D.'s memory as well. She was from Smyrna and came to Volos after the Greek-Turkish war in 1922. Just at the age of 11 she worked for the first time in Matsagos. The "hide and seek" between the young girls and the Labour Inspectors, as well as with the foremen was one of her first impressions in the factory: "The foreman chased us... they hide us in the toilets or into the huge cigarette boxes... if not, the foreman L.D. chased us, beating us... slapping us...”, Georgia D. painted a bitter picture in the most vivid way of the presence of child labour in Matsagos. It is possible that this represents the general picture of the Greek cigarette industry regarding female child labour during the interwar period.

It could be argued that the almost absolute power exercised over the young girl by the foremen, and in many cases by other male and female adult workers, left its marks on the bodies of these children, sometimes forcing these bodies to become "invisible" in the workplace or, at other times, subjugating the bodies of young female workers through the use of violence. That's exactly what the "hide and seek" reveals to a great extent. However, at the same time, this "hide and seek" among girls, foremen and Labour Inspectors reveals another perspective of this relationship in the workplace, which I believe is particular significant: the young female workers did not passively accept the foremen's power. On the contrary, they appear disobedient, they react and they resist and eventually become factors of intentional action. They realize that there are always possibilities for resistance and disobedience, irrespectively of how threatening a given context can be (Foucault, 1987: p. 57). In what follows, 
we will analyze how the technology and the mechanization of production affected the labour division in the Matsagos cigarette industry, the people that worked in the machinery and the labour sections and what their role was.

\section{Reconstructing the Labor Process at Matsagos during the Interwar Period}

The technical reports from the archive of the Matsagos cigarette industry describe the level of mechanization of the factory almost from the beginning of its operation until its final closure in 1972. Combined with other records, such as the "workers registers" from the same archive from the 1920s and 1930s, one can see the level of mechanization in the interwar period and also partially reconstruct the labor process. The firm's "workers registers" confirm the predominance of female labor at Matsagos during the interwar period. From one such register we can see the work sections that operated in the factory, the number of male and female workers and their position in the labour process (Table 2).

Eight hundred and fifty nine workers are listed in the "worker's register" for the years 1928-1932. Of these, 732 were women and just 127 were men. The date of their hiring as well as the section in which each worker was occupied appears on the register. During that period, the following sections were in operation in the factory: packing, wrapping, package-making, cigarette-machines and cutting (blends). Most of the work by female workers is concentrated in the packet-making and packing sections. More specifically, the majority of the workforce appears in the packet-making sector, where during the 1920s the work was carried out entirely by hand: 356 people, of which 329 are women and just 27 men. Correspondingly, in the packing and packaging sections, where work was also done manually, the prevalence of women labour is striking. Just 2 are men in the packing of a total of the section's 114 people and 16 in packaging of a total of 129 workers in that section. In contrast, there seems to be a prevalence of a male workforce in those sections that were, at least up to a certain level, mechanized in the early 1920s. This is particularly noticeable in the cutting section, where there is only one woman worker out of a total of 33 workers. In the section of cigarette-machines, although the number of men and women is equal—49 men and 49 women—, the difference between the two genders is "qualitative": men operated the machines, whereas women worked as an "auxiliary" workforce that is they were occupied as "collectors”. Now we can see more analytically the workplace of Matsagos industry. The description on the labour process below is based on an analytical examination of the firm's archive material and specifically on technical reports, payrolls and employees' cards.

The factory consisted of four floors and occupied two blocks. The tobacco industry departments which were directly related to the production process were the following: "Blends" or "Productive tobacco crops", "Cigarette machines”, "Packaging”, "Packing”, "Packet-making” and "Lithography”, "Wrapping”. The entrance to the factory was through a big arcade, which was vertical to the city's central road, also the location of the factory premises, Figure 3. Entering the factory, one would come across the Tobacco Tax Office.

The officers in charge in the State Tobacco Tax Office first granted a permit for tobacco transportation and possession to the cigarette industry. The tobacco crops were transported from the merchants to the firm's tobacco warehouses. Then, the tobacco crops were transported to the factory to select and mix the tobacco and make the "blend", the mixture of tobacco required for each separate brand of cigarette, Figure 4. The specific process took place in the "Blends" section, or as it was otherwise called "productive tobacco crops".

Only a few men worked among the mostly women workers in the section that was housed on the factory's first floor. The people in charge of the section, though, were a few skilled craftsmen and the blenders who were responsible for the final mixture required for each brand of cigarette. The final blend was made in the chemical

Table 2. Employees by section and gender at Matsagos between 1919-1932.

\begin{tabular}{cccccc}
\hline Section & Packing & Packaging & Packet-making & Cigarette machines \\
$\begin{array}{c}\text { Male } \\
127\end{array}$ & 2 & 16 & 27 & 49 \\
$\begin{array}{c}\text { Female } \\
732\end{array}$ & 112 & 113 & 329 & 49 & 32 \\
$\begin{array}{c}\text { Total } \\
859\end{array}$ & 114 & 129 & 356 & 98 \\
\hline
\end{tabular}

Source: Matsagos archive, employees register 1928-1932. 


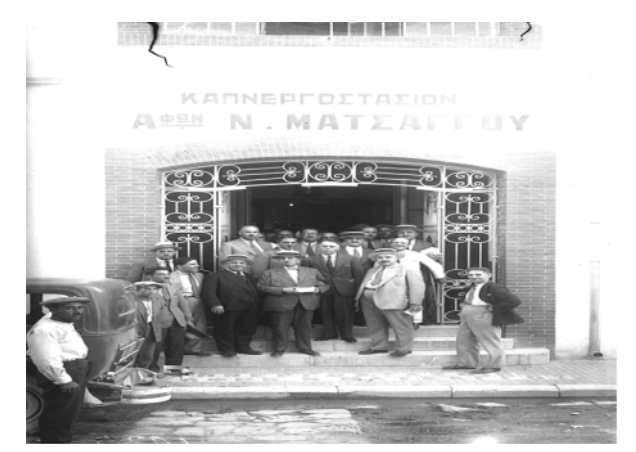

Figure 3. The entrance of Matsagos tobacco factory in 1920. (Zimeris’ Archive).

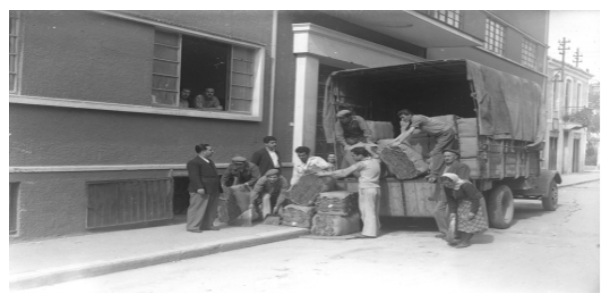

Figure 4. The entrance of Matsagos tobacco factory in 1920. (Zimeris’ Archive).

laboratory of the cigarette industry, which was on the third floor of the factory. Under the instructions and the orders of the "blenders", the women workers of the particular section took over and mixed various portions with tobacco leaves. The work on the blends was difficult and unhealthy and many women workers suffered from various diseases, such as bronchial asthma, because of the dust they inhaled. This may explain the fact that women workers who worked in blends were frequently absent from work. From the payrolls in the archive one can observe that many women workers in the blends section were regularly absent from the factory due to illness. Besides the blenders, the other men who worked in the section were mostly responsible for transporting and cutting the tobacco and supervising the women at work. After the blending of the tobacco, the workers carried the uncut tobacco leaves to the Tobacco Tax Office on the ground floor of the factory, where they were inspected by State officials in order to be taxed.

The Tobacco Tax Office officials weighed the imported tobacco, deducted 5\% from its weight for the inevitable damages it had incurred, and charged the (tobacco) industry with the quantity of cigarettes that it had to submit as sales tax. At the same time, on the basis of this quantity, the Tobacco Tax Office applied tax strips. The tax strips were placed on the cigarettes packets meant for consumption, after the number of packets had been counted and checked by Tax Service officials. The strips were stuck onto the boxes exclusively by women workers in the "Tapes"/Strips section, on the second floor of the factory. Only women are registered next to the sign "Tapes" in the "Workers' Payment Book" for the years 1925-1926, specifically, nine women workers who worked in groups of three or four. Tobacco was also cut on the first floor of the factory. The uncut blend was carried there in trolleys from the Tobacco Tax Office by male workers. With the tobacco-cutting machines, the leaves of the blend were cut in thin, uniform fibers, usually 4 - 6 millimetres wide at the most, depending on the variety and the origin of the tobacco. The tobacco was cut to allow the mixture to burn in an easy, constant and uniform manner during smoking. Male workers cut the tobacco and their role was to operate and maintain the tobacco-cutting machines.

When the new tobacco-cutting machines were introduced to the tobacco industry, new facts were created in the production process. The power driven tobacco-cutting machines replaced the old hand-operated ones, which were called "havania". According to oral testimonies from people who were occupied in the cigarette industry, the workers who worked in the hand-operated tobacco-cutting machines-those who may not have been fired due to the introduction of the new machinery - had to adapt to new conditions and work in the new machinery. The handlers placed the tobacco leaves in the funnel of the machine and spread them slightly on the belt that conveyed the leaves forward to the machine's blades. Two other workers made sure the blades of the tobacco-cutting machine were sharp, so as to ensure that the tobacco was cut accurately and to prevent it from 
crumbling. The quality of the result depended on a regular and specific supply of the tobacco-cutting machines with tobacco leaves, combined with the proper machine maintenance. The blended tobacco, the mixture, was afterwards placed in wooden boxes where it remained to shed its superfluous moisture and to complete its homogenization. From there, it was carried in the wooden boxes with a moisture content of about $13 \%$ - $14 \%$ to the section with the cigarette-making machines, which was on the same floor. There, the cigarettes took their final form.

The final stage of cigarette preparation took place in the cigarette-making machine section. The payrolls show a small predominance of men over women in this specific section. It was the only section where there were slightly more men than women. The basic characteristic of the labour process in this stage of production, too, was the gender division of labour. That means that men and women had different tasks and assumed specific responsibilities. The men worked as handlers of the cigarette-making machines. Also, male workers carried and distributed the cigarettes, first from the cigarette-machines to the dryer and from there to the packaging section. It should be noted, finally, that the heads in the section of the cigarette-making machines were male engineers. The women in this section were occupied as "collectors", Figure 5.

To make each cigarette, the handlers of the cigarette-making machines placed the tape of the cigarette paper in the special staples of the machine and the "feeders" put the mixture of the cut tobacco in the feeding funnel. The cigarette's final form was created through several mechanical operations, following which the cigarettes finally came to the "cigarette-collector". The job of collecting the cigarettes from the machines was executed by women, the "collectors of 'cigarette-machine' cigarettes". The women workers who worked as "collectors" gathered the cigarettes together and placed them in crates. At the same time, other women workers, the "cigarette sorters", sorted out the "faulty" cigarettes that did not meet the required standards for consumption. On the crates and on special index cards, women workers wrote the number of the blend and the cigarette-making machine, the serial number of the crate and the date that the cigarette was made. Then, the crates with the cigarettes were carried by male workers to the second floor and initially to the dryer to be aired and to further reduce moisture. Then, after an appropriate amount of time in the "dryer", the cigarettes were finally carried to the packaging section, where the cigarettes were placed in several different types of packet.

The packaging section, which was on the second floor of the cigarette factory, consisted mostly of women. The few men who were occupied in the specific section were heads, head assistants, transporters and supervisors of women workers who worked as packers. The technical reports are revealing regarding the level of mechanization in this section of production. The packaging in packs of ten packets was carried out manually, Figure 6. The role of the women "packers" was to put the specific brands of cigarettes in the corresponding packets. The women workers sat in double benches and packed the cigarettes by hand, Figure 7. Each one had to pack, at an appointed time, a specific number of cigarettes. She could also produce extra output, which would secure higher

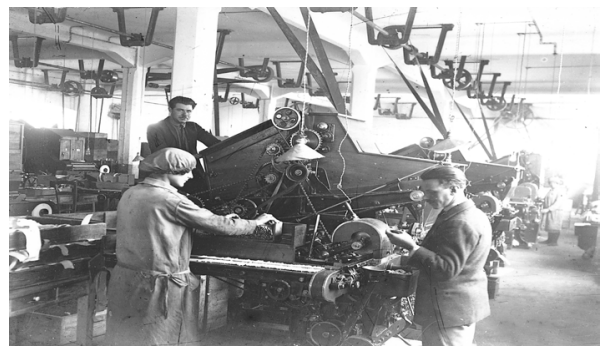

Figure 5. The department of cigarette machines of Matsagos (1920s). (Zimeris’ Archive).

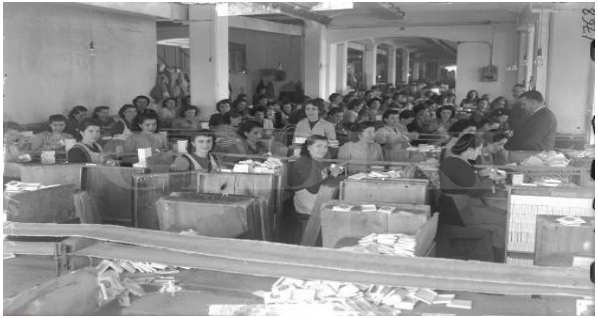

Figure 6. The department of packaging of Matsagos (1920s). (Zimeris’ Archive). 


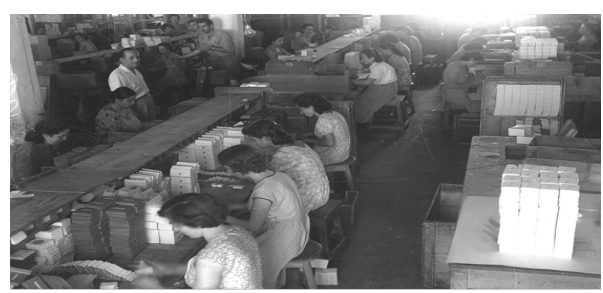

Figure 7. The department of packaging of Matsagos (1920s). (Zimeris’ Archive).

wages. Working in packaging seemed to have required certain basic abilities. The women workers who worked in the specific post had to move their hands very quickly and without interruption in order to meet the firm's requirements. The workers that were not efficient to the degree specified by the business were fired or, at the best of times, moved to a different department.

Zoi S., who worked in the tobacco industry for 24 years from 1938 until 1962 mostly as a "packer", remembers: “...the best and fastest women (workers), the "first hands", worked in packaging." Anna M. worked in Matsagos for 13 years (1938-1951). She worked mainly as a "packer": "We were shown the work of a packer by the older ones. There was also a woman who was in charge and showed us how to fill the different packets. But we had to learn fast... There were also many who didn't learn and were sent away". It appears that packaging required a kind of skill and "specialization" that the women acquired after a short "apprenticeship". It is worth noting that the dexterity of the manual work of the women workers in the packaging section played an important role in the production process and, by extension, in the profits of the business. The faster the women worked, the more packets of cigarettes were channelled into the market for consumption.

For this reason, the foremen exerted constant pressure on the packers to intensify the pace of their work and their performance. This had two consequences for them. On the one hand, the packers were forced to work at an exhausting pace, but on the other, they could —at least theoretically — earn more money than the women workers who were occupied in other posts, as they were paid separately for their extra production. The presence of the foremen is clearly visible in the photos. One can see that the female workers standing next to one another or one behind the other were continuously under the strict supervision of the foremen. This fact is particularly apparent mainly in those departments of the factory where production had not been mechanized, such as packing and packaging (see Figures 6-8). It could be argued that a crucial factor that shaped the organization of labour, the geography of the workplace at Matsagos and the spatial distribution of employees was the "need" for surveillance and control of the workers. This case is not based only upon photographic material but also rests on "evidence" from the Matsagos archive. Besides personal data such as age, origin and marital status, employee personnel cards included the post of each worker in the workplace and special remarks that "accompanied" each worker concerning his or her performance, his or her working ability, as well as the reasons of his absence from work or any misconduct. This record, which essentially places each worker within the context of a document, places them at the same time within the field of surveillance. Through this record the workers were identified and evaluated. As M. Foucault argued, the power of documents emerges as a component element of the mechanism of the surveillance (Foucault, 1975).

As one looks at the photos and walks through the workplace at Matsagos in one's imagination, and by keeping in mind the personnel documents of its employees, one has a strong sense of surveillance in the atmosphere. The foremen continuously monitor the presence and the performance of the female workers, the quality of their work, by comparing them to each other. Eventually, they classify them according to their skill and speed, by observing closely the successive stages of production and by introducing a kind of discipline. At the same time, some of the "fastest" packers were "upgraded" as women in charge and placed at the head of the women workers. In this way, in addition to the higher wages they received in comparison with the others, they seem to have gained reputation and prestige among the women workers. Maria M. worked in the cigarette industry-mainly as a packer-from 1953 to 1967. In relation to the above, she says: "There were some women workers whose hands were working even faster than the machines... They stood out and over the years the best became women in charge... supervisors... They earned more... and the bosses respected them". From the evidence of the women workers who worked in Matsagos, we can see that the women nursed feelings of pride for their skill and productivity in the workplace.

The packet-making and the lithography were on the third floor of the factory. In the section of packet-making, 


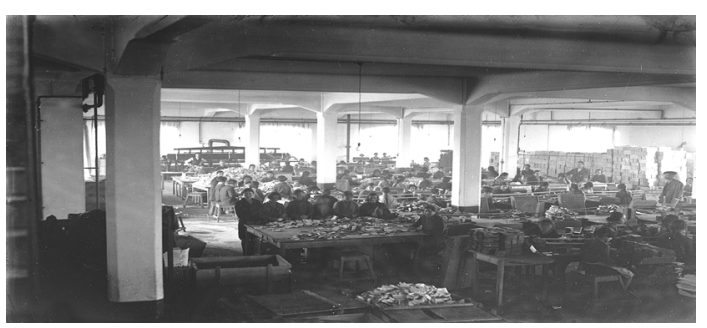

Figure 8. The department of packet-making of Matsagos (1920s). (Zimeris’ Archive).

different packets of cigarettes were made, whereas in the lithography the packets were printed with patterns and texts. Both men and women worked in packet-making. The number of women workers in this section was three times that of men. The men in packet-making were employed as heads of the section, handlers and in machine maintenance, but also as transporters and supervisors. Until the early 1950s, the making of packs in tens was carried out manually and exclusively by women workers, Figure 8 . The women workers in the section of packet-making sat in benches in groups of ten and before the introduction of machines they made several packets only by hand.

The packet-making machines as well as the carving machines that carved the cardboard with which the cigarette packets were made were introduced in the factory in the late 1950s. However, it becomes clear through technical analytically reports that the introduction of machines to the section of packet-making brought about changes in the labor process and seems to have threatened the position of women workers in this section. It seems that with the mechanization of production, many women workers in the packet-making section either lost their jobs or became completely "unskilled". Nevertheless, this was not the case for all. On the contrary, a number of women workers were moved to new posts, acquiring new "skills", for example "group-cluster workers", "workers of ruling-machines" and "workers of sticking of necks and covering boxes". The oral testimony of Georgia K., who worked in the tobacco industry of Volos from 1948 to 1969 mainly in the sections of packetmaking and packaging, is characteristic: "When they brought the machinery, there was no work and they sent away many. Some of us were taken to other sections... where there was work. They took us to blends, too... we carried (packs-boxes) cartons as well... Those who didn't produce much were sent away first".

However, this situation did not apply to everyone. On the contrary, a number of women workers were occupied in new posts, acquiring new "specialties", such as "complex workers", "workers of ruling machines", (pasting) "sticking on necks and covering packets". As Ch. Sabel has argued when the market pushes for cost reduction, businesses are "driven" to greater automatization and that automatization consequently leads to a replacement and readjustment of the responsibilities of each employee (Sabel, 1982: pp. 96-97). Something similar seems to have been partially true at the Matsagos tobacco firm. Georgia K., the same woman we saw earlier, describes the working process in the packet-making section: "When the machinery came, the workbenches were dispensed with and they took us to "complexes" (complex: packet-making machines). They brought us four such complexes in the section. Each machine had five women. One girl put the paper, another the cap cover, and another one put the paper for the bottom. Where it was covered, there was a woman who stopped the machine if it jammed. Finally, a woman was at the end of the band and collected the packets...”.

The last stage of the process was the gathering and packaging of the packets that had been filled with cigarettes. The cigarette packs were gathered and packed in parcels of one or half a kilo and placed in wooden or very thick paper boxes. This work was done in the packaging section on the third floor. Then, the boxes went down to the ground floor with the factory's elevator and were gathered in the packing section. Finally, from there they were either driven to the storehouses or immediately loaded on trucks, to be channelled to the firm's local agencies and finally to the market.

\section{Conclusion}

The introduction of machines in cigarette-making in the first decades of 20th century offered a powerful weapon of extortion of labour and appropriation of surplus-value to cigarette manufacturers. Because it replaced skills, mechanization increased the productivity that is potentially included in a given quantity of work effort or skill. The mechanization not only allowed the use of a more disciplined and cheaper workforce, but also increased the 
reserve army of the unemployed who competed for the specialized positions and made those who had a job more and more dependent on the employers. At the same time, the mechanization of production in the field of cigarette-making brought about changes in the labour process and in the organization of labour. The introduction of machines and the gradual automation of production resulted in an even bigger division of labour within the production process and created new professional specialties. But at the same time, many of the old "traditional" posts remained and co-existed in the factory with the new ones. The new specialties, however, created new hierarchies within the production system. The question was who was occupied in the "best" posts from a perspective of remuneration and prestige and who in the "secondary" and auxiliary positions.

The use of technology at the Matsagos factory did not concern only men, nor were the new posts that mechanization created intended exclusively for men, as both men and women were occupied at the machines. But there was a clear differentiation and gender segregation in the relationship of men and women regarding the technology and the roles they assumed in the labour process. The well-paid jobs were very few and concerned a small part of the male workforce. It became clear from the archive's payrolls that the wage ceiling was formed to a great extent on the basis of the hierarchy that emerged from the specialties. The employees with technical knowledge were the most skilled in the factory and besides their higher wages we could say that they wielded significant power over those men and women who were dependent on their knowledge.

In contrast, those who lacked special technical knowledge were occupied in jobs that on the whole were considered auxiliary and secondary and were paid lower. The picture that one gets from the business's payment books is one of wage inequalities between several groups and sections of its staff. The inequality appears mostly between the male and female wages but is not only across genders. There are also wage inequalities between employees in different working sections. Generally, female labour is paid much lower than male. It is indicative that even the best-paid female wage is lower than the lowest male wage. Therefore, after the implementation of the technological changes that saved effort and replaced skills, some vitally important groups of workers maintained control over the organization of labour in the factory. The managerial organization allowed these small but important groups of workers to exert a certain control over recruitment, training, supervision and control of the unskilled workers regarding the repair and the speed of operation of the mechanical equipment and the division of labor in the workplace. As far as female labour was concerned, it could be argued that it was not homogeneous. There were contrasts in its interior, concerning the kind of labour, the particular specialties and the salary levels. The concept of "specialization" of the female labour in the cigarette industry was not associated with technical knowledge but with the skill and the ability of women workers to work as fast and efficiently as possible. This "ability" determined and differentiated as much the ceiling of the payment of each worker, as the position she had in the hierarchy in the place of production.

Finally, we would notice that the productivity of Matsagos was not based as much or only on the machinery but mainly on the labour intensity of female labour, and more specifically of young women refugees from Asia Minor, as parallel to the mechanization of production traditional posts that required manual work also remained. That means that the increase in productivity and the resultant expansion of the factory which becomes obvious during the interwar period is based on a complex system of labour organization which concerns the different systems of labour remuneration, the occasional occupation, the strict supervision and punishment of those who do not follow the rules, and generally the systems that are constructed on relations of exploitation, discipline and control of the workforce. As elsewhere, here too, it seems that the cheaper price of female labour is the main reason of its "domination" over the men one. Ultimately, the benefits and the success of Matsagos factory during the interwar period may not have come as much from the wide-scale mechanization of production, but from the fact that the factory system on the whole allows greater control of the labour process. The discipline and the supervision within the factory could lower business costs, without necessarily being technologically superior.

\section{Sources}

Matsagos Archives, Personnel Register Cards.

Matsagos Archives, Workers’ Payment Book of N. Matsagos Bros Tobacco Factory, 1925-1926.

Matsagos Archives, Technical Report of Census Machinery, March 1968.

Oral Testimonies (Zoi M., Anna M., Maria M., Georgia K., Georgia D., Maria A.)

Zimeris's Archive. (Photos). 


\section{References}

Avdela, E. (2002). The Women, Social Issue. In Ch. Chatziiosif (Ed.), History of Greece in the 20th Century (p. 343). Volume BI, Athens: Vivliorama.

Balsoy, G. (2009). Gendering Ottoman Labor History: The Cibali Regie Factory in the Early Twentieth Century. International Review of Social History, 54, 45-68. http://dx.doi.org/10.1017/S002085900999023X

Beinin J. (2001). Workers and Peasants in the Modern Middle East. Cambridge: Cambridge University Press. http://dx.doi.org/10.1017/CBO9780511612800

Christopoulos, C.H. (1911). Commerce Guide of Volos. Volos: Pilio-Almyros, 46-47.

Dictionary of Municipalities, Parishes and Settlements of Greece, Censuses in 1881, 1889, 1907.

Dritsa, M. (2004). Greek Businesses in the 20th Century, Persons and Activities. Athens: Kerkira, 64-69.

Foucault, M. (1987). Power, Knowledge and Morality, [in Greek], Zizis Zarikas (Translator). Athens: Ipsilon, 57. (1975). Surveiller et Punir, (Naissance de la prison), Gallimard.

Galvez-Munoz, L. (2006). “Gender, Cigar and Cigarettes. Technological Change and National Patterns”, Session 14, Technology, Gender and the Division of Labour. XIV International Economic History Congress, Helsinki, 21-25 August 2006, 10. (1997). "Breadwinning Patterns and Family Exogenous Factors. Workers at the Tobacco Factory of Seville during the Industrialization Process, 1887-1945”. International Review of Social History, 42, 87-128. http://dx.doi.org/10.1017/S0020859000114804

Hannah, L. (2006). The Whig Fable of American Tobacco, 1895-1913. The Journal of Economic History, 66, 66-67. http://dx.doi.org/10.1017/s0022050706000027

Hastaoglou, V. (2007). Volos. The Portrait of a City from the 19th Century until Today, Volos, 46-47.

Jones, B. W. (1984). Race, Sex and Class: Black Female Tobacco Workers in Durham, North Carolina, 1920-1940, and the Development of Female Consciousness. Feminist Studies, 10, 441-451. http://dx.doi.org/10.2307/3178034

Labrianidis, L. (1982), Industrial Location in Capitalist Societies: The Tobacco Industry in Greece, 1880-1980, Unpublished PhD. Thesis, London: L.S.E., 126.

National Statistics Department, Industry Census, Athens 1928.

Porter, R. (1969). Origins of the American Tobacco Company. Business History Review, 43, 59-76. http://dx.doi.org/10.2307/3111987

Radcliff, P. (1993). Elite Women Workers and Collective Action: The cigarette-makers of Gijon, 1890-1930. Journal of Social History, 27, 85-108. http://dx.doi.org/10.1353/jsh/27.1.85

Sabel, Ch. (1982). Work and Politics. The Division of Labor in Industry. Cambridge: Cambridge University Press, 96-97. http://dx.doi.org/10.1017/CBO9780511571572

Schechter, R. (2006). Smoking, Culture and Economy in the Middle East: The Egyptian Tobacco Market 1850-2000. London.

Volos Guide (1901). Magnesia Prefecture. Department of Statistics of Commercial Association of Volos, 86. 